\title{
REFLEXIVIDADE E CRITICIDADE NO ENSINO DE GRADUAÇÃO EM ADMINISTRAÇÃOO
}

\author{
REFLEXIVITY AND CRITICALITY IN UNDERGRADUATE EDUCATION IN MANAGEMENT
}

Recebido em 25.10.2015. Aprovado em 18.02.2016

Avaliado pelo sistema double blind review

DOI: http://dx.doi.org/10.12712/rpca.v10i1.683

\author{
André Luiz Kopelke \\ kopelke_professor@yahoo.com.br \\ Universidade Federal de Santa Catarina (UFSC), Florianópolis/SC, BRASIL
}

\section{Sérgio Luís Boeira}

sbsergio267@hotmail.com

Universidade Federal de Santa Catarina (UFSC), Florianópolis/SC, BRASIL

\section{Resumo}

O ensaio objetiva levantar a hipótese de que existe uma lacuna no ensino de administração no que se refere à reflexividade e à criticidade e, como consequência, há necessidade de estudos empíricos e novos ensaios que possibilitem avaliações consistentes dos cursos visando sua atualização. As Diretrizes Curriculares Nacionais (DCNs) estabelecem habilidades técnicas e reflexivas aos egressos dos cursos. Porém as matrizes curriculares parecem priorizar conteúdos técnicos, em detrimento da formação reflexiva, ética, criativa e crítica. Como consequência, graduados em administração aparentam ter limitada capacidade de avaliar criticamente seus atos e limitações para propor soluções aos dilemas enfrentados pela sociedade contemporânea. $O$ ensaio apresenta um panorama do pensamento crítico em administração, a partir de uma abordagem pluralista, considerando a diversidade epistemológica desse campo de estudos.

Palavras-chave: Reflexividade. Criticidade. Graduação em administração. Diretrizes curriculares. Diversidade epistemológica.

\begin{abstract}
The study aims to hypothesize that there is a gap in management education with regard to reflexivity and critical thinking and, consequently, the need for empirical studies and new essays that enable consistent evaluations of courses aimed to updating them. The National Curriculum Guidelines (DCNs) establish technical and reflective skills to the graduates of the courses. But the curriculum matrices seem to prioritize technical content, rather than reflexive, ethics, creative and critical education. As a result, graduates in business administration appear to have limited ability to critically evaluate their actions and limitations to propose solutions to the dilemmas faced by contemporary society. The essay provides an overview of critical thinking in administration, from a pluralistic approach, considering the epistemological diversity of this field of study.
\end{abstract}

Keywords: Reflectivity. Criticality. Undergraduate in management. Curriculum guidelines. Epistemological diversity. 


\section{Introdução}

As Diretrizes Curriculares Nacionais (DCNs) dos Cursos de Administração no Brasil (CNE, 2005) estabelecem um conjunto de competências e habilidades a serem desenvolvidas entre estudantes de graduação. Tais competências compreendem o domínio de técnicas funcionais típicas da administração, mas incluem também capacidade reflexiva, crítica, lógica, ética, analítica e criativa para que os egressos dos cursos de graduação possam exercer plenamente sua profissão.

Entretanto, a realidade dos cursos de graduação em administração em território nacional parece estar bem distante dos ideais almejados pelas Diretrizes Curriculares Nacionais. À exceção de alguns poucos cursos de excelência, o ensino de administração tem sido caracterizado, segundo nossa hipótese, por uma ênfase excessiva nas disciplinas funcionais e nas metodologias gerenciais. As matrizes curriculares e os projetos pedagógicos dos cursos de graduação sequer esclarecem seu posicionamento epistemológico, adotando a lógica do mercado como a única a ser considerada correta.

A consequência de tal prática tem sido, aparentemente, uma formação precária de estudantes, o que, em princípio, torna-os incapazes de refletir criticamente sobre as consequências de seus atos em ambiente de trabalho. A limitada formação reflexiva pode transformar os acadêmicos em administração em meros operadores gerenciais, expectadores da realidade organizacional.

Como efeito dessa limitada formação, vemos, segundo a bibliografia consultada (por exemplo, SARAIVA, 2011; FISCHER, 2006; GUERREIRO RAMOS, 1989), que profissionais acríticos são incapazes de distinguir a diferença entre os vários modismos de gestão e as contribuições efetivas para a evolução da ciência das organizações. O perfil de a-luno (termo que etimologicamente significa aquele que não tem luz própria), resultante da formação deficiente, parece conduzir a um limitado senso ético e grande dificuldade de questionamento de posturas unilateralmente instrumentais. $\mathrm{O}$ ambiente de acriticidade e irreflexividade da maior parte dos cursos de administração no Brasil pode ser fator decisivo no perfil de administradores propensos a cooperar, de forma acrítica, com práticas abusivas implementadas pelas organizações. Se esse argumento tem alguma pertinência, conforme nossa hipótese, a educação em administração, que deveria contribuir para a emancipação humana e a transformação social, passa a funcionar basicamente como reprodutora de relações utilitaristas de trabalho em favor do interesse de alguns grupos privilegiados, além de não contribuir para o enfrentamento da crise de valores que perpassa toda a sociedade (GIROLETTI, 2005).

Pretende-se argumentar no presente ensaio que a ciência da administração falha quando se apresenta como conjunto de disciplinas funcionais e metodologias gerenciais. Toda uma perspectiva crítica em administração é, nesse caso, negligenciada no ensino de graduação, o que prejudica a formação reflexiva dos estudantes. $O$ que se pretende sustentar, hipoteticamente, é que há uma lacuna na implementação das DCNs e que há, portanto, a necessidade de estudos empíricos e novos ensaios sobre o tema, considerando-se o amplo espectro de estudos críticos no pensamento administrativo ainda em grande medida ignorados nos cursos de graduação, especialmente naqueles inseridos em universidades particulares e comunitárias (com gestão privada). Sua inclusão, mesmo que marginal, nas matrizes curriculares dos cursos de graduação, poderia contribuir significativamente para o fortalecimento da formação reflexiva, crítica, criativa e ética dos profissionais em administração no Brasil.

Para sustentar a hipótese acima, recorrer-se-á, nos tópicos seguintes, a uma bibliografia que sugere uma discussão a respeito da precariedade da formação reflexiva dos acadêmicos de graduação em administração. Em seguida, serão apresentadas, de forma breve, algumas concepções de pensamento crítico em Administração. Discutir-se-á sobre as diferentes perspectivas críticas dos estudos organizacionais e a contribuição de pesquisadores e estudiosos brasileiros para o tema. Por fim, serão reunidos alguns argumentos em defesa do ensino de perspectivas críticas na graduação em administração como recurso para o fortalecimento da formação reflexiva dos administradores.

\section{Orientação gerencialista/funcionalista dos cursos de graduação em administração}

A estruturação dos cursos de graduação em administração no Brasil tem sido fortemente influenciada, desde sua origem, pelo pensamento norte-americano. Essa influência inicia-se nos 
na década de 1950 com a ampliação da inserção do capital estrangeiro no país (RODRIGUES; CARRIERI, 2001). Os primeiros cursos superiores de administração surgem no Brasil ao longo dessa década, período no qual, no plano internacional, desenrolavase a guerra fria (BERTERO; ALCADIPANI, 2012); no plano nacional, vivíamos o auge da perspectiva desenvolvimentista promovida pelo pensamento cepalino (BIELSCHOWSKY, 2000).

Em 20 de janeiro de 1949, o Presidente norteamericano Harry S. Truman, em seu discurso de posse, estabelece uma série de pontos que iriam nortear a política externa dos Estado Unidos com o objetivo de afastar a ameaça comunista da América Latina, entre eles, o Ponto IV, destinado a promover a prosperidade e o desenvolvimento econômico, seguindo os preceitos dos EUA. Dessa forma, os Estados Unidos financiaram uma série de projetos de assistência técnica em países em desenvolvimento como forma de propagar o seu modelo de produtividade ao redor do mundo.

Um desses projetos resultou na criação do curso de Administração da EAESP/FGV, com um acordo com a Universidade de Michigan que durou mais de uma década (1954-1965) no qual extenso apoio técnico e financeiro foi dado para a consolidação do curso. Bertero e Alcadipani (2012) consideram esse processo como a porta de entrada de um tipo específico de administração que preza pela eficácia, pela eficiência e pela maximização dos resultados e que se pretende política e ideologicamente neutro. Vale ressaltar que havia alternativas ao modelo norte-americano. Porém, houve uma opção deliberada da FGV em adotar o modelo dos vizinhos do norte, considerado mais "moderno" (BERTERO; ALCADIPANI, 2012, p. 291) para atender às necessidades de um país que clamava por desenvolvimento econômico.

A experiência da EAESP forneceu o apoio necessário para criação de cursos nos mesmos moldes na UFBA e na UFRGS. Convênios semelhantes foram realizados com a University of Southern California (USC) para cursos na área de Administração Pública (SERVA, 1992).

O modelo de ensino de administração importado dos Estados Unidos não passou pelo processo de redução sociológica definido por Guerreiro Ramos (1958), ou seja, não foi devidamente adaptado ao contexto brasileiro, e não levou em consideração as características peculiares da sociedade nacional. Até mesmo o acervo das bibliotecas foi formado com bibliografia importada.
A forte influência norte-americana consolidou no Brasil uma visão de management fortemente influenciada por um modelo funcionalista que percebe a organização por uma ótica instrumental composta por um sistema de tarefas a serem executadas e objetivos a serem atingidos. A empresa é vista como um sistema de papéis organizados de acordo com uma hierarquização funcional de tarefas a serem implementadas, cuja responsabilidade pela execução fica a cargo de agentes com competências e habilidades específicas (AMADO; FAUCEUX; LAURENT, 1994).

A influência do modelo importado perdura, segundo nossa hipótese, até os dias atuais por conta de uma inércia estrutural fruto da influência de corporações que dominaram o ensino do campo (FISCHER, 2006) e pela atuação do Ministério da Educação e do Conselho Federal de Educação, que estabelecem um isomorfismo curricular, impondo um currículo mínimo fortemente estruturado sobre disciplinas de caráter funcionalista. $O$ Parecer $n^{\circ}$ 307, de 08/07/1966, do então Conselho Federal de Educação, fixa o primeiro currículo mínimo do curso de Administração no Brasil, tendo como referencial a Lei n. ${ }^{\circ} 4.769$, de 09/09/1965, que pouco tempo antes havia regulamentado o exercício da profissão de "Técnico de Administração". A Resolução no 2, de 4/10/1993 expedida pelo Conselho Federal de Educação pouco avançou em relação à normativa anterior, mantendo a política de currículo mínimo com ênfase em disciplinas de caráter funcional/ instrumental.

Somente com a instituição das Diretrizes Curriculares Nacionais para os cursos de Administração pela resolução CNE-CES n ${ }^{\circ} 4$ de 13 de julho de 2005, os currículos mínimos são extintos. As novas diretrizes curriculares permitem uma maior flexibilidade da organização curricular e buscam servir de referência para que as instituições de ensino promovam a formação de egressos providos de espírito crítico, reflexividade e competências intelectuais que reflitam a heterogeneidade das demandas sociais (RIBEIRO; SACRAMENTO, 2009).

Apesar do maior poder conferido às Instituições de Ensino Superior (IES) na concepção de suas estruturas curriculares, Ribeiro e Sacramento (2009) identificam que boa parte das IES prefere replicar modelos curriculares consagrados, vistos como modelos de sucesso. Vale lembrar que os cursos de graduação em administração no Brasil apresentam um dos maiores 
índices de matrículas do ensino superior, chegando próximo a um milhão de estudantes matriculados em 2013, considerando-se apenas o ensino presencial (INEP, 2013). Além disso, 87,3\% dessas matrículas foram realizadas em IES privadas.

Apesar da regulamentação dos cursos de administração ter-se tornado mais flexível apenas na última década, ela não pode ser considerada o fator determinante da insuficiente inovação dos bacharelados e da ausência de originalidade nas propostas curriculares. A prática mais comum das IES tem sido seguir literalmente as determinações legais criando uma matriz curricular fiel à norma, porém despersonalizada, sem identidade própria, que não atende às necessidades da comunidade local. O resultado é a produção em massa de bacharéis em escolas de administração que se parecem com fábricas de administradores (NICOLINI, 2003).

Grey (2010, p. 200), ao tratar do contexto anglo-saxão, afirma que:

[...] não há absolutamente qualquer evidência de que fazer um curso de administração tenha qualquer efeito em transformar as pessoas em gerentes melhores do que já eram, sendo, inclusive, possível que esses cursos acabem por torná-los ainda piores. As escolas de administração são, em sua maioria, fundamentadas em um mito que distorce a teoria da organização (GREY, 2010, p. 200).

O mito a que se refere o autor é o do controle da gestão por meio de recursos quantitativos: "seu valor é o de contribuir para o projeto maior da justificação técnica e ideológica do gerenciamento" (GREY, 2010, p. 222). Esta "mentalidade controladora", diz o autor, "está fadada ao fracasso" (GREY, 2010, p. 222). O controle seria, em tese, parte de um viés pragmático visando gerar ordem. Mas, ao contrário do que alguns afirmam, a visão dominante em administração não é, rigorosamente falando, pragmática. Cabe considerar que o termo pragmatismo tem sofrido enorme degradação, perdendo seu vínculo com a filosofia educacional do pragmatismo - que implica em "reconstrução da experiência" (DEWEY, 1965, 31) e, portanto, requer reflexividade. Isto nos remete à questão da subjetividade.

$\mathrm{Na}$ abordagem dominante, via de regra percebe-se a organização e a sociedade como dados, entidades que existem por elas mesmas, nas quais o indivíduo não tem sua subjetividade considerada, a menos que seja um gerente. De acordo com Rouleau (2007, p. 220), "percebe-se que a subjetividade nas organizações foi, historicamente, relegada a segundo plano nas correntes dominantes da administração". Por pressuposto, não existem antagonismos. O consenso é a regra geral e eventuais conflitos são disfunções tratadas no plano psicológico. A baixa produtividade, a falta de interesse, a lentidão no trabalho são aspectos vistos, de forma unilateral, como problemas comportamentais e de caráter do trabalhador não ajustado aos determinantes instrumentais e utilitários da lógica empresarial. Isto não significa negar (muito pelo contrário) a relevância do estudo de aspectos comportamentais e dos padrões culturais no Brasil (HOLANDA, 1979; SORJ, 2000; SOUZA, 2015).

A visão funcionalista determina que o indivíduo deva adaptar-se à organização e não o contrário. Os que não se adaptam são os "atrasados", "preguiçosos", "incultos" e "retrógrados", não afinados com a sociedade globalizada de mercado, e por isso precisam ser excluídos. Esse modelo, quando é aceito tacitamente e não questionado, pode servir como suporte ideológico do poder estabelecido. Cabe reconhecer, contudo, que o chamado paradigma funcionalista tornou-se mais complexo e diversificado no final do século XX, conforme observam Caldas e Bertero (2007).

Os saberes práticos, que moldam comportamentos, orientam decisões, estabelecem procedimentos e normas de funcionamento nos ambientes organizacionais refletem a construção de um sistema de interpretação do mundo social que implica numa ordem de valores e numa concepção de ação que Gaulejac (2007) denomina ideologia gerencialista. Essa ideologia, conforme já observamos, se apresenta como pragmática e racional, envolta num verniz de cientificidade, fundada sobre a eficácia da ação, mas é, na abordagem crítica do autor, um projeto de dominação dissimulado, orientado pelo mercado, que mantém a ilusão da neutralidade das técnicas e da modelação das condutas humanas.

Nesse contexto, a reflexividade é considerada disfuncional, pois tem um potencial contestador e perturbador da ordem. A emancipação passa a ser vista como uma ameaça ao status quo empresarial. A ideologia gerencialista favorece uma visão de mundo na qual o ser humano é tratado como recurso a serviço da empresa, e o questionamento desta lógica pode ser considerado perverso para os fins utilitaristas da organização. 
A ideologia gerencialista, herdeira da tradição funcionalista e positivista, impregna as matrizes curriculares da ampla maioria dos cursos de graduação em administração no Brasil. Como resultado, levantamos a hipótese da lacuna acima referida, a ser confirmada, negada ou relativizada por pesquisas empíricas; segundo tal hipótese, há um crescente contingente de egressos relativamente bem adaptados às necessidades instrumentais dos ambientes organizacionais, mas de baixíssima capacidade reflexiva. As instituições de ensino, empenhadas em atender às demandas do mercado, nem se preocupam em estabelecer parâmetros epistemológicos em seus projetos pedagógicos. Assumem o funcionalismo como dado e legítimo, e o implementam por meio de uma matriz curricular repleta de disciplinas funcionais e gerenciais. Em alguns casos, até mesmo o ensino das disciplinas funcionais fica comprometido pela baixa qualidade e total ausência de reflexividade no contexto do próprio funcionalismo, a partir de um ensino baseado na simples memorização e na pedagogia comportamentalista.

Essa situação, sugerida pela literatura pertinente ao tema, implica num cenário desolador para o ensino de graduação em administração no Brasil em que a educação converte-se numa commodity (SARAIVA, 2011), sendo concebida, produzida e comercializada como tal. Os cursos superiores de administração, em pouco mais de meio século de história, tornaramse o carro chefe da educação superior brasileira, compreendendo $18,5 \%$ do total de matrículas no ano de 2009 . Desse total, mais de $87 \%$ são oferecidas pela iniciativa privada (INEP, 2010). Uma razão para isso está no fato de que a abertura de cursos de administração apresenta-se vantajosa em termos econômico-financeiros (NICOLINI, 2003), pois não implica em pesados investimentos em laboratórios sofisticados, nem num refinamento tecnológico muito acentuado. $\mathrm{O}$ baixo custo de implantação do curso associado a uma demanda elevada em todo o território nacional transforma a oferta de cursos de administração numa atividade comercialmente lucrativa. Além disso, muitas escolas de administração oferecem seus cursos de uma forma completamente desvinculada do processo de construção científica, o que reduz ainda mais os custos operacionais.

Operando dentro da lógica mercantil, os cursos de administração se mostram como negócios rentáveis que tentam maximizar outputs (diplomados) e minimizar inputs (investimentos diversos, incluindo a qualificação docente) (ALCADIPANI, 2011). Quando a educação é tratada como negócio, formar um acadêmico crítico e reflexivo, além de caro, pode ser perigoso, pois este pode vir a questionar a própria lógica do processo educacional. Uma postura de delinquência acadêmica (TRAGTENBERG, 1979), onde professores fingem que ensinam e estudantes fingem que aprendem (GIANNOTTI, 1986; SOUZA-SILVA; DAVEL, 2005) mostra-se como uma estratégia adequada quando o objetivo principal é a rentabilidade do empreendimento-educação.

Se tal argumentação tem consistência, conforme nossa hipótese, a educação em administração está perdendo seu papel transformador, convertendo-se em mero instrumento de reprodução de relações de dominação preexistentes.

\begin{abstract}
Este formato de ensino, embora aparentemente neutro e sem pretensões além da formação profissional, prejudica o avanço das perspectivas teóricas e aplicadas da Administração porque condena muitos profissionais a serem pouco mais do que apenas expectadores do que se passa nas organizações [...]. Apenas o que não funciona nos modelos de gestão chama sua atenção, já que a prescrição funcionalista de sua formação se baseia em ordem e previsibilidade. Voltam-se, assim, para identificar muitas vezes apenas sintomas de problemas, e raramente para analisar suas causas, o que traduz uma visão despolitizada e uma aceitação passiva e obediente da versão dada da organização e de seu ordenamento (SARAIVA, 2011, p. 44).
\end{abstract}

Desenvolve-se, assim, uma formação profissional comprometida com o resultado econômico/ financeiro das organizações, mas não com a sociedade. Apresenta-se a ideia de que o que é bom para o resultado da empresa maximizadora de lucros é bom para a sociedade como um todo (SOUZA, 2015). Dessa forma, pode-se deduzir que a educação de administração no Brasil, ao enfatizar a técnica e negar a reflexão, desumaniza o estudante e o reduz a um animal domesticado e adestrado para os fins utilitários da organização, convertido num "alegre detentor de emprego" (GUERREIRO RAMOS, 1989, p.98), numa sociedade (centrada no mercado) em que o emprego formal tem se tornado crescentemente descartável.

As disciplinas funcionais, as técnicas gerenciais e os princípios positivistas de organização dos processos empresariais tiveram seu mérito ao longo dos últimos séculos. É inegável que a sociedade moderna, 
alicerçada sobre tais princípios, incrementou de forma significativa a afluência material e o bemestar de parcelas crescentes da população. $O$ paradigma sociocultural da modernidade ocidental teve sua importância enquanto força emancipadora da humanidade, mas parece plausível sustentar que estamos vivendo o ocaso desse modelo de organização social. O fato de ainda permanecer como paradigma dominante deve-se à inércia histórica (SANTOS, 2011).

Grey (2010, p. 217) acrescenta que as escolas de administração podem desempenhar "um papel importantíssimo nos projetos ideológicos do capitalismo globalizado de promover e, especialmente, socializar estudantes em uma representação saneada da gestão corporativa".

Atualmente, os estudos organizacionais atravessam uma destruição das certezas (REED, 1998, p. 89), em relação a suas fundações ontológicas, epistemológicas, compromissos teóricos, convenções metodológicas e predileções ideológicas. Os pressupostos das abordagens funcionalistas têm sido incinerados por críticas ferozes à sua "arrogância teórica inata e sua pretensão metodológica". Diante dessa situação Reed (1998), concordando com Law (1994), vê duas respostas possíveis. Uma primeira opção seria avançar a qualquer custo reforçando o paradigma vigente, orientado pelo mercado, o que implicaria numa "reclusão às fortificações intelectuais que oferecem proteção contra os efeitos radicalmente desestabilizadores da crítica contínua e da desconstrução, desde que seja feita uma reforma adequada dessas fortificações" (REED, 1998, p. 89). Esta é uma opção que agrada ao status quo.

Outra opção seria procurar novos paradigmas. Para isso, é preciso estimular uma continuada proliferação de "mais questões e incertezas e [...] mais narrativas que gerem questões" (LAW, 1994, p. 249), algo que só é possível se os profissionais de administração puderem ser sensibilizados para a necessidade de preservar e utilizar o pluralismo intelectual viabilizado pelo pensamento crítico, aqui tomado em sentido amplo.

Se os cursos de graduação em administração pautarem suas matrizes curriculares, e seus conteúdos didáticos, unicamente por disciplinas de caráter funcional/gerencial, estarão viabilizando a expansão da sociedade mercadocêntrica (GUERREIRO RAMOS, 1989). Num mundo em que os princípios fundamentais da ciência clássica (determinismo, redução e disjunção) se transformaram num obstáculo para o progresso do conhecimento (MORIN, 2007a), e onde a "Espaçonave Terra" é impulsionada por quatro motores descontrolados (ciência, tecnologia, economia e busca de lucro) rumo à autodestruição (MORIN, 2007b), a busca por alternativas se mostra urgente. E tais alternativas não estão disponíveis nas disciplinas funcionais/gerencialistas, típicas dos cursos de administração. Essas alternativas, conforme se argumenta nesse ensaio, podem ser buscadas dentro de uma perspectiva crítica que reconheça o papel social do administrador com maior amplitude, levando-se em conta tanto as DNCs quanto a literatura crítica nos estudos organizacionais, com uma abertura à contribuição interdisciplinar entre administração e sociologia, antropologia, filosofia, psicologia, ciência política etc.

O próximo tópico é destinado a apresentar, de forma introdutória, algumas das concepções do pensamento crítico em administração.

\section{Pensamento critico em administração}

O que significa ser crítico em administração? Ser crítico não é simplesmente apontar defeitos e propor soluções. Davel e Alcadipani (2003) elencam três características fundamentais para que um estudo em administração possa ser considerado crítico: (1) visão desnaturalizada da administração; (2) intenção desvinculada da performance; e (3) intenção emancipatória.

A perspectiva funcionalista em administração tende a abstrair o processo e o contexto histórico de formação social. As instituições são vistas como dadas, não construídas. Suas origens, fruto de escolhas conflituosas e relações de poder, são desconsideradas. Os teóricos dessa corrente costumam construir um edifício teórico ordenando a realidade de forma que lhe seja pertinente, utilizando para isso critérios de racionalidade e cientificidade. A perspectiva crítica, por outro lado, considera que a história e as relações de poder importam. As instituições não são dadas. Elas são construídas dentro de um jogo de forças e interesses, e atendem de forma privilegiada a grupos específicos. E a organização é uma construção social e histórica fortemente influenciada pelas relações de poder que se estabelecem no seu entorno e dentro dela. Do ponto de vista da perspectiva crítica, abstrair 
a história e desconsiderar as relações de poder na formação das instituições e organizações é uma forma de manipulação destinada a atender interesses particulares.

Outro aspecto fundamental é que os estudos críticos em administração não buscam gerar conhecimentos que incrementem resultados econômico/financeiros das organizações. Não estão preocupados com a maximização da produção nem com a redução de custos operacionais. Os estudos críticos não são orientados pelo predomínio da racionalidade instrumental, mas pela delimitação desta por uma racionalidade substantiva (GUERREIRO RAMOS, 1989).

Além disso, os estudos críticos em administração buscam enfatizar e promover o potencial da consciência humana de modo que os profissionais da área possam refletir sobre práticas opressivas das organizações. O objetivo dessa reflexão é ampliar o nível de autonomia e responsabilidade das pessoas na elaboração de julgamentos que não sejam deformados ou enviesados por questões relativas à subordinação e desigualdades de riqueza, poder e conhecimento (DAVEL; ALCADIPANI, 2003).

Outro aspecto importante a ser avaliado é a questão do enquadramento do pensamento crítico dentro dos subcampos do conhecimento em administração. Existem pelo menos três grandes corpos de ideias (subcampos) nos estudos de administração (FRANÇA FIHO, 2004): (1) as técnicas ou metodologias gerenciais, (2) as áreas funcionais e (3) a teoria das organizações, também chamada de estudos organizacionais.

O subcampo das técnicas e metodologias gerenciais compreendem um conjunto de ideias sustentadas por parâmetros de racionalidade instrumental destinadas a auxiliar o trabalho do gerente. São regras e procedimentos orientados por conceitos de eficiência e eficácia administrativa. As técnicas gerenciais são conduzidas por um cálculo utilitário de consequências que ignoram qualquer tipo de questionamento sobre a validade ética da ação. Só o que é útil é considerado válido, mas não se pergunta para quem ou para que a ação é útil. O conhecimento produzido por este subcampo é de natureza prescritiva e trata de aspectos operacionais da empresa e do seu compromisso com resultados econômico-financeiros.

As áreas funcionais da administração compartilham com o subcampo anterior suas principais características.
Também são estruturadas pela lógica da racionalidade instrumental, e também estão a serviço dos resultados econômico/financeiros da organização. Estas áreas funcionais compreendem as especializações da prática administrativa e se originam do processo de divisão do trabalho. Atualmente, as áreas funcionais mais comuns são marketing, finanças, recursos humanos e produção. Mas novas áreas tendem a surgir (gestão da informação, etc.) à medida que o processo de divisão de trabalho se intensifica e novas tecnologias são incorporadas aos processos organizacionais.

O terceiro subcampo da administração, o da teoria das organizações, deixa de se preocupar com o trabalho em si, e passa a estudar o contexto onde o trabalho é executado, ou seja, o universo organizacional. A teoria das organizações nasce nos EUA por volta os anos 1950 e se sustenta em dois pilares fundamentais: a abordagem comportamentalista e a abordagem estruturalista das organizações. Ambas as abordagens estão fortemente influenciadas pelo paradigma funcionalista e estão comprometidas com uma visão utilitarista da organização. A abordagem comportamentalista, desconsiderando a introspecção ou reduzindo a subjetividade a um mecanismo de estímulo-resposta, busca controlar o comportamento do indivíduo, considerado incapaz de realizar julgamentos éticos.

Entretanto é dentro desse último subcampo da administração que se desenvolvem outras abordagens genericamente chamadas de "estudos críticos" (FRANÇA FILHO, 2004). Tais abordagens focalizam dimensões da análise organizacional não abordadas ou minimizadas pela perspectiva funcionalista. Para a perspectiva crítica, o objeto de estudos da administração não é apenas a gestão em si, enquanto prática, mas a própria organização como um fenômeno social. Entretanto, uma abordagem crítica não-unilateral, aberta à inter e à transdisciplinaridade, não é incompatível com descrições e análises das práticas, desde que contextualizadas, considerandose o contexto organizacional, institucional, cultural, político, geográfico e biofísico. A multiplicidade de aspectos a considerar depende da problemática tal como é definida e percebida pelo pesquisador.

O interesse pela abordagem crítica em administração vem ampliando-se nos últimos anos e a amplitude de temas, métodos e perspectivas tem-se tornado tão extensa que vários autores já realizam classificações dos estudos organizacionais críticos. Um dos trabalhos mais recentes sobre o tema é o estudo de Faria (2009). 
O autor considera que o campo dos estudos críticos pode ser classificado em quatro grandes áreas: (1) a teoria crítica frankfurtiana, (2) a teoria crítica em estudos organizacionais, (3) a critical management studies, e (4) a análise crítica em estudos organizacionais.

A primeira grande área segue as orientações teóricas e filosóficas da Escola de Frankfurt. Esta se divide, por sua vez, em três gerações distintas: a primeira ligada à tradição marxista, a segunda liderada por Habermas e uma terceira orientada pelos trabalhos de Hometh. (FARIA, 2009).

A teoria crítica em estudos organizacionais baseia seus estudos e pesquisas de campo no marxismo focando a centralidade do trabalho. Também estuda temas relacionados à psicologia social e histórica, à psicossociologia crítica e formas democráticas de gestão.

A abordagem conhecida como critical management studies realiza seus estudos críticos dentro da perspectiva da gestão. Os principais autores dessa corrente são Alvesson e Willmott. Esta grande área não é considerada por Faria (2009) uma perspectiva crítica legítima, pois seus trabalhos não apresentam um caráter revolucionário, mas apenas reformador. Seus atores apenas eventualmente fazem uso de conceitos marxistas, segundo ele.

A análise crítica em estudos organizacionais engloba autores não marxistas e não frankfurtianos que estudam as organizações do ponto de vista das relações de poder. Incluem pós-estruturalistas, pósmodernistas, análises institucionais, do simbolismo, do imaginário e da teoria da complexidade, ou, conforme preferimos denominar, do pensamento complexo ou epistemologia da complexidade ${ }^{1 .}$

A classificação proposta por Faria (2009) não é a única. Existem classificações alternativas sustentadas por outros autores. Davel e Alcadipani (2003) diferenciam três perspectivas críticas: a escola de Frankfurt, os estudos pós-analíticos e as teorias feministas. Paula et al. (2010) diferenciam o movimento do critical management studies de base pós-estruturalista dos Estudos Organizacionais Críticos, fortemente inspirados no humanismo radical.
O importante neste caso é perceber que a administração não é uma ciência fechada e pronta. O conhecimento administrativo e organizacional está em construção. Mas um denominador comum a essas correntes críticas é a resistência às limitações do behaviorismo, do positivismo e do funcionalismo. Para Reed (1998) a administração é uma ciência que está passando pela fase revolucionária em termos kuhnianos, o que torna comum a existência de conflitos internos e desacordos sobre fundamentações ideológicas e epistemológicas.

O pensamento crítico no Brasil sofreu forte influência de três pensadores em especial: Alberto Guerreiro Ramos, Maurício Tragtenberg e Fernando Prestes Motta. Este último (MOTTA, 1986; 2003) foi influenciado pelos dois primeiros, especialmente por Tragtenberg. Nos parágrafos seguintes, destacaremos, brevemente, a trajetória e o pensamento de Guerreiro Ramos e de Tragtenberg. O primeiro foi influenciado é considerado um humanista radical e o segundo um pós-estruturalista (PAULA et al, 2010). As escolhas teóricas desses autores não foram importadas de nenhum autor estrangeiro em especial, mostrando certa autonomia dos estudos organizacionais críticos no Brasil em relação à produção externa (PAULA et. al., 2010). Os estudos desses autores destacam temáticas relacionadas à autonomia dos sujeitos e à autogestão, questões consideradas de forma marginal nos critical management studies.

Nascido em 13 de setembro de 1915 em Santo Amaro da Purificação, município da região metropolitana de Salvador, e falecido em 06 de abril de 1982 em Los Angeles, EUA, desde cedo Guerreiro Ramos destacouse como um intelectual ao escrever ensaios regulares para o diário O Imparcial de Salvador e para algumas revistas literárias de circulação nacional (AZEVEDO, 2006, p. 12). Em 1939, aos 24 anos de idade, mudouse para o Rio de Janeiro e em 1942 diplomou-se em ciências sociais pela Faculdade Nacional de Filosofia do Rio de Janeiro (Universidade do Brasil), bacharelando-se um ano depois pela Faculdade de Direito, também no Rio de Janeiro.

Assessorou o presidente Getúlio Vargas durante seu segundo governo, atuando, em seguida, como diretor do departamento de sociologia do Instituto

\footnotetext{
${ }^{1}$ Embora Faria (2009) aponte Edgar Morin como referência da teoria da complexidade, este autor se refere mais especificamente ao que denomina pensamento complexo ou epistemologia da complexidade, distinguindo-se dos autores que defendem a teoria da complexidade justamente por esta, segundo ele, carecer de fundamentos epistemológicos, críticos, e se deixar envolver pela epistemologia dominante, acrítica. Há, com efeito, diversas abordagens da complexidade em disputa no meio acadêmico (MORIN, 2007b; ALHADEFF-JONES, 2008).
} 
Superior de Estudos Brasileiros (ISEB). Esse instituto constituiu um dos núcleos mais importantes de formação da ideologia "nacional-desenvolvimentista" que impregnou todo o sistema político brasileiro no período compreendido entre a morte de Vargas, em 1954, e a queda de João Goulart, em 1964.

Ingressou na política partidária em 1960, quando se filiou ao Partido Trabalhista Brasileiro (PTB), de cujo diretório nacional participou. No pleito de outubro de 1962 candidatou-se a deputado federal pelo então estado da Guanabara, na legenda da Aliança Socialista Trabalhista, formada pelo PTB e o Partido Socialista Brasileiro (PSB), obtendo apenas a segunda suplência. Ocupou uma cadeira na Câmara dos Deputados de agosto de 1963 e abril de 1964, quando teve seus direitos políticos cassados pelo Ato Institucional n ${ }^{\circ} 1$.

Guerreiro Ramos deixou o país em 1966, radicando-se nos Estados Unidos. Passou a lecionar na Universidade do Sul da Califórnia, atuando junto à School of Public Administration, obtendo reconhecimento e sucesso, o que fica evidenciado pelo fato de ter recebido três vezes o prêmio Teaching Excellence Award of the School of Public Administration (AZEVEDO, 2006, p. 17).

Somente a partir de 1979 o sociólogo pensa em retornar ao Brasil, mas seus estudos, nesse momento, não estão mais voltados para as questões desenvolvimentistas. Guerreiro Ramos encontravase, então, envolvido com a formulação de sua Teoria da Delimitação dos Sistemas Sociais, bem como com as primeiras reflexões visando aplicação ao contexto brasileiro, como será visto logo adiante.

No ano de 1980, em visita ao Brasil, Guerreiro Ramos estabeleceu planos para atuar como professor visitante junto à Universidade Federal de Santa Catarina. Infelizmente, sua passagem por esta instituição foi muito breve, pois o sociólogo veio a falecer pouco tempo depois. Sua obra tem sido objeto de vários estudos (AZEVEDO, 2006; BARIANI Jr., 2011) e obteve, recentemente, um reconhecimento internacional, pois em 2014 a Fundação Getúlio Vargas (FGV) e a University of Southern Califórnia (USC) decidiram criar a Cátedra Internacional Guerreiro Ramos (CAVALCANTI; DUZERT; MARQUES, 2014).

Em nosso entendimento, é fundamental que a obra de Guerreiro Ramos não seja enquadrada nos limites do que Burrel e Morgan (1979) denominaram "paradigma humanista radical", já que isto significaria reduzi- la a um enfoque muito restrito. Guerreiro Ramos (1989) destacou-se por transcender os limites das ciências sociais. Criticou as ciências mecanomórficas (positivistas) e também as sociomórficas, entre as quais inclui a abordagem de Habermas. Guerreiro Ramos, além disso, iniciou um diálogo com a termodinâmica e com a ecologia, em sua última obra, na qual dá início a uma ciência multidimensional das organizações e a uma reconceituação da riqueza das nações.

Outro expoente do pensamento crítico em administração no Brasil é Maurício Tragtenberg. Ele nasceu em 4 de novembro de 1929, num assentamento rural no interior do Rio Grande do Sul, que deu origem ao atual município de Erechim. Faleceu em 17 de novembro de 1998 em São Paulo. É filho de camponeses de origem judaica que chegaram ao Brasil fugindo das perseguições da Rússia Czarista aos judeus (progoms) na década de 1910. Ainda criança Tragtenberg muda-se com a família para Porto Alegre em busca de melhores condições de vida. Pouco tempo depois, a família empreende outra mudança, desta vez para São Paulo, vindo a se estabelecer no bairro judaico de Bom Retiro (TRAGTENBERG, 1999).

Por ocasião da queda do Estado Novo, a família de Tragtenberg muda-se para o bairro do Brás, um bairro operário, onde o autor brasileiro passa a ter contato com integrantes do Partido Comunista do Brasil. Trabalhou como escriturário do Departamento de Águas e Energia Elétrica de São Paulo onde estabeleceu contato com a burocracia do quotidiano e o ritualismo da interação burocrática. Essa experiência prática com a burocracia foi fundamental para sua crítica à organização burocrática realizada em estudos posteriores. Seu horário de trabalho na época, do meio-dia às 18:00 hs, permitia que frequentasse a Biblioteca Municipal Mário de Andrade no período da manhã e à noite, onde podia ler e discutir temas de seu interesse com outros autodidatas.

Apesar de ler muito, Tragtenberg ingressa tardiamente no mundo acadêmico formal. Inicia o curso de graduação em Ciências Sociais na USP, mas não se adapta à rotina escolar. Preferia o estudo solitário. Presta novo vestibular para História e conclui o curso em 1959 (SILVA, 2008). Inicia sua carreira docente ministrando aulas no curso de Magistério em escolas do interior paulista. Com o golpe militar de 1964 Tragtemberg é vítima de delações e perseguições que resultaram em demissões e dificuldades de arrumar emprego. Apesar das dificuldades, Tragtemberg consegue defender sua tese de doutorado pelo 
Departamento de Ciências Sociais da USP em 27 de abril de 1973, apresentando o trabalho Burocracia e Ideologia. Na condição de Doutor, inicia-se o auge de sua carreira acadêmica, quando passa a ter acesso a Universidades como a PUC, FGV, Faculdade de Educação da Unicamp, dentre outras.

A crítica de Tragtenberg às teorias administrativas e à burocracia está diretamente relacionada ao pensamento anarquista que sustenta uma visão libertária e que defende a autogestão como caminho para a emancipação humana. Normalmente, o termo "anarquismo" está sujeito a uma simplificação conceitual e costuma ser confundido com uma negação do Estado. Na verdade, anarquismo significa "contrário à autoridade". Um anarquista que propõe uma sociedade sem Estado e sem governo não está sugerindo uma sociedade caótica, sem nenhum tipo de organização. $\mathrm{O}$ anarquista propõe uma sociedade autogestionada, sem autoridade e burocracia, ou seja, uma sociedade organizada de maneira autônoma, a partir de suas próprias bases, fundamentada na educação integral de seus indivíduos (PAES DE PAULA, A. P., 2008).

$\mathrm{Na}$ obra Burocracia e ideologia (1985) Tragtenberg analisa com profundidade a obra de Weber e afirma que o sociólogo alemão não estuda a burocracia para salientar suas virtudes organizacionais, mas o faz para refletir como podemos nos defender de seu avanço implacável que resulta numa crescente perda de significado da vida e perda da liberdade. Tragtenberg concorda com o diagnóstico de Weber sobre a burocracia, mas discorda dele quando este afirma que o caminho para a democracia é o parlamento. Tragtenberg considera a autogestão uma via muito mais frutífera para a democracia.

A crítica que Tragtenberg faz às teorias administrativas diz respeito ao bloqueio que estas representam para a autogestão, na medida em que estabelecem a separação entre o planejamento e a execução do trabalho, oprimindo e controlando trabalhador. As teorias administrativas expressam-se ideologicamente manifestando ideias desprovidas de contexto histórico que escondem a verdadeira natureza da situação. Dessa forma, as teorias administrativas manipulam a percepção da realidade organizacional por parte dos trabalhadores, criando supostas harmonias administrativas, e ocultando as verdadeiras tensões e conflitos.

Tragtenberg é especialmente crítico da Escola
Comportamental que procura legitimar uma ideologia participacionista. Para o autor, as organizações, ao utilizarem técnicas participacionistas, estimulam nos funcionários uma consciência de que são importantes no processo decisório, quando, na verdade, apenas endossam decisões já tomadas. Além disso, a Escola Comportamentalista psicologiza os problemas do trabalhador, fazendo com que este tenha a sensação que seus problemas são de ordem pessoal, e não estão relacionados com o contexto social de seu trabalho. Ou seja, o trabalhador passa a acreditar que sua inadequação ao trabalho é fruto de um desajustamento de sua personalidade. Com isso, os conflitos de poder são encobertos e equacionados.

A alternativa, para Tragtenberg, é a valorização da autogestão e da organização da produção em bases democráticas e cooperativistas pelos próprios trabalhadores. Na visão de Paes de Paula (2008) a produção de Tragtemberg é de grande importância para o contexto administrativo atual, pois diante da decadência do socialismo real e da crise do neoliberalismo, o anarquismo, entendido como auto-organização e autogestão, emerge como uma utopia de nosso tempo. Movimentos de resistência à globalização e ao neoliberalismo são organizados em redes horizontais, segundo princípios de descentralização e na democracia não hierárquica. Ao negar a autoridade, mas não a organização, o anarquismo defendido por Tragtenberg pode evitar as armadilhas da organização burocrática e abrir espaço para novos modelos organizacionais.

De acordo com Paula et al (2020), Guerreiro Ramos e Tragtenberg inspiraram uma série pesquisadores no país que deram continuidade aos seus trabalhos. Por exemplo, Ramon Moreira Garcia, Maurício Serva e Fernando Guilherme Tenório tomaram Guerreiro Ramos como referência. Os principais pesquisadores influenciados pelo pensamento de Tragtenberg são Fernando Prestes Motta e José Henrique de Faria (PAULA et. al., 2010).

Entre os temas recorrentes encontrados nos estudos críticos em administração realizados pelos pesquisadores brasileiros, observam-se conteúdos relacionados a dominação e ideologia, controle e disciplina, estudos de gênero, exclusão social e cidadania, sofrimento físico e psíquico no trabalho, além de vários outros (DAVEL; ALCADIPANI, 2003).

De grande importância para a tradição dos estudos 
críticos em administração são os trabalhos realizados em língua francesa. Os pesquisadores franceses, ao contrário dos americanos, concebem um modelo personalista e social de organização segundo o qual a empresa é vista como um sistema de pessoas organizadas hierarquicamente seguindo um princípio de distribuição vertical da autoridade. A ênfase está na clarificação hierárquica das relações de autoridade entre os atores (AMADO et. al., 1994). Estes estudos mostram que, nos países de cultura latina, é muito difícil diferenciar a autoridade funcional da autoridade pessoal, o que faz com que as relações hierárquicas sejam vividas de forma mais personalizada. A atitude dos executivos de países de cultura latina conduz a um grau superior de centralização da autoridade, o que suscita uma gama rica e diversificada de atitudes de independência entre os subordinados. Esse conflito de interesses produz um terreno fértil para a originalidade de pensamento, para a criatividade e a inovação. É interessante notar que o Brasil, por ser um país cuja cultura é, em grande medida, herdeira da tradição latina, enfrenta realidades, conflitos e tensões organizacionais semelhantes (mantidas as devidas proporções socioeconômicas) às encontradas em organizações francesas.

Os trabalhos críticos em língua francesa também são muito diversificados e nove correntes de pensamento podem ser identificadas (CHANLAT, 2006; SÉGUIN; CHANLAT, 1992): a) análise estratégica; b) análise sociocultural; c) análise psicossociológica; d) acionalista; e) sistêmica; f) sociopolítica; g) antropológica; h) comunicativa; i) epistemológica. A corrente da análise estratégica, fruto dos trabalhos de Crozier, Sainsaulieu e Friedberg, considera que cada ator buscará otimizar sua estratégia para tornar-se o mais autônomo possível no ambiente organizacional. A corrente da análise sociocultural, também influenciada pelos trabalhos de Crozier, mas formada por uma série de outros autores franceses, busca ligar os fenômenos organizacionais a traços culturais próprios da sociedade. A terceira corrente, de análise psicossociológica, tem em Pagès e Enriquez seus principais autores e investiga os investimentos afetivos que o indivíduo mantém com a organização e que são fundamentais para a constituição de grupos organizados. A corrente acionalista, representada principalmente por Touraine, considera que a organização é atravessada pelas grandes questões e conflitos que agitam a sociedade na qual ela se insere. A corrente sistêmica, por sua vez, baseia-se nas ciências biológicas e físicas e faz uso das noções de auto- organização, sistemas e complexidade. Há diversas variantes do sistemismo - das mais próximas ao funcionalismo até abordagens mais interdisciplinares, construtivistas, críticas e complexas, conforme argumenta Le Moigne (1977). A corrente sociopolítica tenta articular as relações políticas internas às relações de poder observáveis na sociedade global. A corrente antropológica tenta compreender os fenômenos humanos nas organizações como fenômenos sociais totais, dentro da perspectiva de Marcel Mauss. A corrente comunicativa reconhece a organização como um lugar de comunicação e se ocupa dos fenômenos relacionados a essa temática incluindo questões de linguagem. Por fim, a corrente epistemológica compreende uma série de autores preocupados em questionar os fundamentos e os limites de suas disciplinas.

Ao constatar a proliferação de escolas e correntes de pensamento, os pesquisadores de estudos críticos em administração reconhecem que o aumento desmedido do número de disciplinas pode trazer efeitos negativos para a produção do conhecimento. A subdivisão dos temas críticos em várias disciplinas pode provocar um esfacelamento dispersivo dos conhecimentos, formando uma infinidade de campos especializados que dificultam a comunicação entre os profissionais das diversas áreas. Cientes dessas limitações, os pesquisadores críticos são muito mais propensos a utilizar abordagens inter, multi e transdisciplinares (FADUL; MAC-ALLISTER DA SILVA, 2009) apoiados em metodologias predominantemente qualitativas (CHANLAT, 2006). Tais metodologias representam um desafio epistemológico para os cursos de graduação, com mudanças na grade curricular, o que implicaria numa dedicação mais intensa à formação para a pesquisa, com um reconhecimento explícito da insuficiência e das lacunas das pesquisas baseadas em epistemologia cartesiana, mecanicista ou positivista. Ao buscarem apoio nas pesquisas predominantemente qualitativas, os pesquisadores críticos adotam uma perspectiva crescentemente complexa (MORIN, 2007a), ou diversos níveis de complexidade, unindo saberes dispersos, promovendo a articulação (sem fusão) entre os conhecimentos do mundo das teorias e do mundo das práticas (MARIOT'TI; ZAUHY, 2013).

Pelo exposto até aqui, é possível perceber que existe um vasto universo crítico a ser explorado pelos cursos de graduação em administração, mas, pelo fato da concepção e estruturação do ensino superior brasileiro nessa área ser voltado hegemonicamente 
para o mercado, toda essa riqueza teórica e conceitual é deixada em segundo plano ou esquecida nas matrizes curriculares, segundo a hipótese que depreendemos da bibliografia consultada. Torna-se muito desafiador formar profissionais reflexivos nesse contexto.

O tópico a seguir destina-se a argumentar a favor da perspectiva crítica como forma de contribuir para a formação de administradores mais reflexivos e autônomos.

\section{Administrador reflexivo e autônomo}

O ensino de administração no Brasil é, hegemonicamente, herdeiro da tradição anglo-saxônica (RODRIGUES; CARRIERI, 2001), resultante do processo histórico de industrialização associada e dependente. Ao herdar as teorias, herdou também seus pressupostos epistemológicos fundamentados no funcionalismo e no positivismo. Essa tradição epistemológica promoveu a divisão do trabalho nos processos produtivos e a divisão dos saberes em disciplinas distintas e de crescente especialização sem intercomunicação entre as especializações.

Cabe observar que esta problemática transcende o caso da administração e diz respeito à história e à sociologia das ciências. Domingues critica a ultraespecialização e a hiperfragmentação:

[...] pode-se dizer que nenhuma época histórica teve tantas disciplinas e campos de conhecimento: mais de $10.000 \mathrm{em}$ fins dos anos 90 - responsáveis, tanto pelas revoluções da ciência e da técnica, que marcaram profundamente o destino da modernidade, quanto pela introdução de toda sorte de barreiras que, nos dias de hoje, acabaram por constituir-se em verdadeiros obstáculos epistemológicos para a expansão do conhecimento, a saber: as barreiras da ultraespecialização do sujeito cognoscente e a hiperfragmentação do saber. [...] hoje, ninguém domina seu campo de conhecimento ou especialidade; a consequência é o fim do especialista, depois do fim do generalista iniciado no princípio dos tempos modernos, em razão do surgimento e cristalização da especialidade disciplinar (DOMINGUES, 2005, p. 18, 19).

A extrema especialização permitiu o surgimento da sociedade de consumo de massa e a formação das economias globalizadas. Os volumes de produção e padrões de consumo cresceram vertiginosamente ao longo do século XX e início do século XXI. Porém, a afluência material teve um custo. As vozes em contrário foram caladas e a ordem social foi modelada de acordo com critérios de economicidade. Uma teoria organizacional baseada na racionalidade instrumental foi criada e uma concepção comportamentalista de natureza humana foi estimulada (FRANÇA FILHO, 2010). O modelo de organização burocrática e os padrões de organização da sociedade industrial avançada se tornaram hegemônicos e inquestionáveis. Os trabalhadores, embevecidos pelo bem-estarmaterial crescente, perderam sua capacidade contestadora (DEMO, 1985), permitindo o surgimento de uma sociedade unidimensional, aparentemente sem alternativas.

Para atender ao status quo, um administrador desprovido de capacidade reflexiva seria muito bem-vindo. Mas a promessa de bem-estar material, grande legitimadora da sociedade centrada no mercado, não está mais garantida. A expectativa de progresso material e social pelo incremento tecnológico, e pela intensificação das relações instrumentais e utilitaristas, está cada vez mais distante (REED, 1998).

O conhecimento tradicional do mundo ocidental, fundamentado no racionalismo instrumental e no positivismo criador de uma visão fragmentária de mundo, está gerando uma série de crises interligadas (MORIN, 2013). Essas crises incluem aspectos financeiros, ecológicos, demográficos, urbanos, rurais, políticos, tecnocientíficos, militares e religiosos. Engloba as sociedades tradicionais, a civilização e a modernidade ocidental. Mas o paradigma funcionalista e a ciência administrativa tradicional estão cegos para as grandes dificuldades enfrentadas pelo mundo contemporâneo.

Mesmo que a sociedade centrada no mercado não esteja esgotada pela sua importância institucional, este é um modelo que possui um caráter excludente, uma vez que o trabalhador é visto como um insumo cujo custo precisa ser reduzido (FRANÇA FILHO, 2010). Esta lógica tem implicações sociais muito graves.

Administradores tradicionais (AKTOUF, 1996), predominantemente reprodutores de uma lógica de mercado amoral e predatório, ao invés de um mercado ético (HENDERSON, 2007; LEISINGER; SCHMITT, 2001), colaboram para intensificar os processos geradores das crises socioeconômicas e, mais amplamente, da insustentabilidade ambiental e social do processo produtivo. Uma limitada capacidade 
reflexiva e responsabilidade socioambiental condena administradores a uma existência conformista, envolvida pela síndrome comportamentalista (GUERREIRO RAMOS, 1989). Seu ajustamento acrítico ao funcionalismo racionalizador gera malestar entre os membros da organização, pois reduz os espaços de valores como solidariedade, tolerância e justiça social. Conduz, pelo contrário, à incongruência de tentar desenvolver-se em um entorno que se empobrece (ETKIN, 2008), se considerarmos o médio e longo prazos, já que tal enfoque administrativo pressupõe políticas mercadocêntricas ou neoliberais, marcadas pela desigualdade social e pela insustentabilidade ambiental e econômica. O desafio da formação de administradores (GRISALES, 2011) atualmente requer uma nova fundamentação filosófica, delimitando-se a ideologia mercadológica que apresenta cursos de administração como um conjunto de ferramentas para o sucesso financeiro.

A propósito da noção de sucesso, caberia retomar a noção de homem parentético de Guerreiro Ramos:

\footnotetext{
[O homem parentético] não iria esforçarse demasiadamente para obter sucesso, segundo os padrões convencionais, como faz aquele que quer subir. Daria grande importância ao eu, e teria urgência em encontrar um significado para a vida. Não aceitaria acriticamente padrões de desempenho, embora pudesse ser um grande empreendedor quando lhe atribuíssem tarefas criativas. Não trabalharia apenas para fugir à apatia ou indiferença porque o comportamento passivo iria ferir seu senso de autoestima e autonomia. Iria esforçar-se para influenciar o ambiente, para retirar dele tanta satisfação quanto pudesse. Seria ambivalente em relação à organização (...). Sua ambivalência seria derivada de sua compreensão de que as organizações, como são limitadas pela racionalidade funcional, têm de ser tratadas segundo seus próprios termos relativos (GUERREIRO RAMOS, 1984, p. 9).
}

Tal atitude poderia ser desenvolvida com uma formação crítica, atenta aos limites do funcionalismo e da lógica de mercado convencional. A formação crítica permitiria ao profissional de administração perceber e compreender a complexidade da realidade organizacional, distinguir mercados sustentáveis de não sustentáveis, etc. A percepção de que a natureza humana (MORIN, 1973) não se limita ao bomo sapiens-faber-homo economicus, ou homo prosaicus, mas inclui também o homo consumens, o bomo ludens, o bomo imaginarius, o bomo aestheticus, o bomo poeticus, formando, assim, um homo sapiens-demens ou homo complexus (MORIN, 2002; FORTIN, 2007), em constante tensão, mas com potencial enorme a ser desenvolvido, representaria uma grande oportunidade de enfrentamento dos dilemas, dualidades, contradições existentes no ambiente organizacional (ETKIN, 2006) e nas próprias teorias organizacionais (REED, 1998).

A capacidade reflexiva de um administrador com formação crítica e autocrítica daria, em tese, instrumentos para uma gestão não preocupada apenas em gerenciar e buscar resultados de curto prazo, mas também para governar com inteligência política (ETKIN, 2006, p. 12), ou seja, com capacidade para perceber as demandas e expectativas dos mais variados públicos/atores com os quais a organização se relaciona. $\mathrm{O}$ uso da inteligência política implicaria na manutenção da coesão e da governabilidade da organização, via elaboração de acordos entre as partes com interesses conflitantes (ETKIN, 2006). Mais amplamente, pode-se argumentar que há um potencial ainda inexplorado de abordagem de múltiplas inteligências (2001).

A formação crítica, em princípio, também despertaria o administrador para os grandes dilemas ambientais enfrentados pela moderna sociedade industrial. A sustentabilidade é uma questão verdadeiramente inter, multi e transdisciplinar que não pode ser tratada dentro dos limites estreitos dos domínios disciplinares. A problemática da sustentabilidade não surgiu historicamente no âmbito de alguma disciplina ou departamento acadêmico. Nesse sentido cabe observar que as diretrizes curriculares nacionais apontam a necessária formação interdisciplinar (CNE, 2005). A sustentabilidade simultaneamente ambiental, social, econômica e institucional parece desafiar o formato convencional de compartimentação do saber e implicar em profundas transformações civilizatórias. No sentido da sustentabilidade multidimensional a obra de Guerreiro Ramos de 1981 (reeditada em 1989) constitui-se como uma inovação singular, à frente de seu tempo, nas ciências sociais e particularmente na ciência das organizações. Nesse sentido, cabe destacar uma afirmação do autor:

O paradigma paraeconômico leva em consideração não apenas a termodinâmica da produção, mas também seus aspectos externos, sociais e ecológicos. Como tal, representa uma alternativa para os modelos clássicos (quer derivados de Smith, quer de Marx), a qual oferece, 
também, o arcabouço abrangente para uma nova ciência das organizações. Nada menos que uma revolução organizacional de alcance mundial faz-se necessária, para superar a deterioração física do planeta $e$ das condições da vida humana, em toda parte (GUEREIRO RAMOS, 1981, p. 190).

O pensamento em gestão ambiental é bastante diversificado e composto por vários enfoques que precisam ser levados em consideração por administradores preocupados com a sobrevivência tanto dos seres humanos quanto dos ecossistemas na biosfera (SINAY, et al., 2013).

A perspectiva crítica, se fosse prioridade nos cursos de administração, também permitiria ao administrador compreender que seu papel não está apenas ligado à lógica utilitarista do mercado. Ele poderia, em tese, também gerir empreendimentos solidários (FRANÇA FILHO, 2010) como as cooperativas populares ou organizações civis de apoio à economia solidária ou ainda órgãos de representação e articulação política. As cooperativas, por deixarem em suspensão duas condições fundamentais da lógica capitalista (a natureza privada dos meios de produção e a existência de força de trabalho livre), rompem, em princípio, com as relações sociais de produção assalariadas criando uma nova forma social de produção. Nesse sentido, a cooperativa é uma forma de reconciliar o trabalhador com os frutos de seu trabalho e superar, em parte, a alienação ao trabalho (GAIGER, 2013).

Mais amplamente, segundo Chanlat (2000), as ciências sociais, delimitando criticamente o management, permitem a reconciliação entre os aspectos econômicos e sociais, para que a gestão não se transforme no que Gaulejac (2007) denominou "gestão como doença social".

Em suma, o mundo passa por transformações significativas, por uma mudança de época e não apenas por uma época de mudanças. As crises econômicas, políticas, sociais, éticas e ecológicas tendem a convergir de forma complexa, sendo mal percebidas e compreendidas por enfoques reducionistas, unilaterais, subordinados a políticas neoliberais ou estatistas, ambas, em princípio, insustentáveis.
Novos caminhos precisam ser trilhados, abertos, construídos. A educação de administradores precisaria, segundo argumento deduzido de nossa hipótese inicial, ter um escopo mais amplo e mais ousado, estimulando novas visões de mundo, de organização, de ser humano e de vida em sociedade. $\mathrm{O}$ administrador precisaria entender o mercado, mas não se subjugar aos imperativos mercadocêntricos ou estatistas ${ }^{2}$.

\section{Considerações Finais}

O presente ensaio procurou sustentar a hipótese segundo a qual há uma lacuna a ser investigada e avaliada no ensino de graduação em administração no Brasil. As Diretrizes Curriculares Nacionais do Curso de Graduação em Administração requerem um perfil de administrador voltado para a valorização da responsabilidade social, da ética e do aperfeiçoamento profissional contínuo, provido de uma visão humana, interdisciplinar e global, com uma formação técnica e científica, além de capacidade empreendedora, crítica, ética e criativa. Dentre as habilidades e competências requeridas para os egressos da graduação em administração, a formação técnica parece ter clara predominância sobre os demais aspectos.

Embora as DCNs criem uma abertura legal para a formação de cursos de graduação com identidade própria, autônomos, interdisciplinares, flexíveis e contextualizados na realidade socioeconômica regional, além de global, permitindo, dessa forma, a inclusão de conteúdos críticos - o que se observa na prática, segundo a literatura especializada, é um conservadorismo curricular (SARAIVA, 2011; FISCHER, 2006), que já perdura por seis décadas, com poucas mudanças. Novas disciplinas são oferecidas, com novos nomes, para o ensino de novas técnicas surgidas com a inovação tecnológica. Os novos rótulos das disciplinas configuram-se como "vinho novo em velhas garrafas" (FISCHER, 2006, p. 398), onde conteúdos instrumentais sofrem alterações cosméticas de modo a ajustá-los aos novos procedimentos produtivos.

\footnotetext{
${ }^{2}$ A insistência no pensamento prescritivo, aqui, pelo uso do verbo "dever", poderia ser questionada, certamente, mas também seria possível ampliar o debate, com a sustentação da legitimidade relativa do pensamento normativo. Segundo Morin (2004, p. 30), "em certo sentido, Hegel não foi suficientemente dialético; desdenhou o sollen, o dever-se. E, no entanto, não apenas o dever-ser, como também o mundo dos sonhos, das aspirações, dos desejos, dos mitos, das vontades, diz respeito à realidade do homem, que é semiimaginária [...]"
} 
O que se pode concluir, hipoteticamente, é que há uma lacuna a ser investigada empiricamente em cada região, nos diversos formatos de cursos existentes, assim como parece necessário ampliar-se o espaço para a reflexão por meio de ensaios críticos sobre a temática - para evitar a simples multiplicação de estudos de caso, de situações pontuais, aparentemente isoladas.

Segundo uma conclusão parcial, porque deduzida apenas da literatura, grande parte dos egressos de cursos de administração são reprodutores de lógicas instrumentais, de caráter funcionalista, que, se no passado tiveram o mérito de promover o bem-estar material para parcelas crescentes da população, atualmente são fontes de graves crises de ordem financeira, ecológica, demográfica, urbana, rural, política, social ética e moral, enfrentadas pela sociedade contemporânea.

Esse comportamento desprovido de percepção crítica permite que os administradores sejam manipulados e atuem em defesa dos interesses de grupos específicos que obtêm vantagens econômicas com a manutenção da atual crise civilizatória.

Também parece plausível concluir que, atualmente, grande parte das pesquisas de cursos de pós-graduação, envolvendo a problemática epistemológica, tende a ser ignorada e desperdiçada, pois encontra um bloqueio institucional para sua inserção nos cursos de graduação, em benefício dos interesses econômicos de grupos isolados.

Este ensaio argumentou que a figura do administrador não pode ficar restrita a um papel de reprodutor de lógicas instrumentais. $\mathrm{O}$ administrador tem o dever moral de agir no sentido de enfrentar as crises contemporâneas, mesmo que isso exija uma reformulação da lógica produtiva. Isso não implica numa ruptura brusca e unilateral da ordem econômica e social estabelecida, porém alternativas precisam ser buscadas, pois a insistência no caminho atual leva, inevitavelmente, a uma série de desastres.

A hegemonia de uma economia orientada exclusivamente por um referencial instrumental como aspecto ordenador da vida em sociedade precisa ser questionada. $\mathrm{E}$ os administradores podem adotar uma conduta objetiva no processo de superação das dificuldades criadas pela moderna sociedade industrial.

Por isso, abandonar o caráter crítico do conhecimento científico e do ensino de administração é um erro estratégico grave (GIROLETTT, 2005), cujas consequências serão cobradas pelas gerações futuras. O empobrecimento cultural na formação dos administradores é um fato que precisa ser combatido para que este profissional passe a ter um papel ativo na construção de uma sociedade justa e sustentável. E todo o conhecimento crítico produzido, seja pelos teóricos brasileiros como Tragtenberg ou Guerreiro Ramos, seja por pesquisadores estrangeiros, não pode ser desperdiçado. Ele precisa ser utilizado em prol da emancipação humana e na construção de uma sociedade mais humana, justa e sustentável.

Por fim, reconhecemos que há limitações nesse ensaio teórico. Uma delas é certa contundência na crítica e na avaliação de causas e efeitos dos problemas da graduação em administração no Brasil. Outra é uma apresentação sumária de enfoques teóricos e epistemológicos que exigiriam um espaço maior para uma argumentação mais consistente do ponto de vista crítico. Como consequência, cabe reconhecer que este ensaio teórico é apenas mais uma tentativa de contribuição ao debate público, bem como reconhecer as dificuldades de representação clara e consistente sobre uma problemática tão complexa.

\section{Referências}

AKTOUF, O. A administração entre a tradição e a renovação. São Paulo: Atlas, 1996.

ALCADIPANI, R. Resistir ao produtivismo: uma ode à perturbação Acadêmica. Cad. EBAPE.BR [online]. vol.9, n.4, pp. 1174-1178, 2011.

ALHADEFF-JONES, M. The three generations of complexity theories : nuances and ambiguities.

Educational Philosophy and Theory, vol. 40, n . 1., p. 66-82. Journal compilation. Philosophy of Education Society of Australasia. Published by Blackwell Publishing, 9600 Garsington Road, Oxford, OX4 2DQ, UK and 350 Main Street, Malden, MA 02148, USA, 2008. Disponível em: $<$ http://onlinelibrary.wiley.com/doi/10.1111/ j.1469-5812.2007.00411.x/abstract > Acesso em: 23 de outubro de 2015.

AMADO, G., FAUCHEUX, C.; LAURENT, A. Mudança organizacional e realidades culturais: contrastes franco-americanos. In CHANLAT, J.F. O indivíduo na organização: dimensões esquecidas volume 2. São Paulo: Atlas, 1994.

AZEVÊDO, A. A sociologia antropocêntrica de 
Alberto Guerreiro Ramos. Tese (Doutorado em Sociologia). Florianópolis: Universidade Federal de Santa Catarina, 2006.

BURREL, G.; MORGAN, G. Sociological paradigms and organizational analysis. London: Heinemann, 1979.

BARIANI Jr., E. Guerreiro Ramos e a redenção sociológica: capitalismo e sociologia no Brasil. São Paulo: UNESP, 2011.

BERTERO, C. O.; ALCADIPANI, R. Guerra fria e ensino do management no Brasil: o caso da FGV-

EAESP. Revista de Administração de Empresas, v. 52, n. 3, p. 284-299, 2012.

BIELSCHOWSKY, R. Cinquenta anos de pensamento na CEPAL - uma resenha. Rio de Janeiro : Record, 2000, p. 15-68.

CAVALCANTI, B.; DUZERT, Y.; MARQUES, E. (Orgs.) Guerreiro Ramos. Coletânea de depoimentos; collection of testimonials. Rio de Janeiro: FGV, 2014.

CALDAS, M. P.; BERTERO, C. O. Teoria das organizações. São Paulo: Atlas, 2007.

CHANLAT, J-F. Análise das organizações: panorama da produção em língua francesa contemporânea (1950-2000). In: CHANLAT, J. F.; FACHIN, R.; FISCHER, T. Análise das organizações: perspectivas latinas. Vol. 1: Olhar histórico e constatações atuais. Porto Alegre: Editora da UFRGS, 2006.

CHANLAT, J-F. Ciências sociais e management: reconciliando o econômico e o social. São Paulo: Atlas, 2000.

CNE (CONSELHO NACIONAL DE

EDUCAÇÃO). Resolução CNE/CES 4/2005.

Institui as Diretrizes Curriculares Nacionais do Curso de Graduação em Administração, bacharelado, e dá outras providências. Diário Oficial da União, Brasília, 19 de julho de 2005, Seção 1, p. 26.

Disponível em: <http://portal.mec.gov.br/cne/ arquivos/pdf/rces004_05.pdf $>$ Acesso em: 23 de outubro de 2015.

DAVEL, E; ALCADIPANI, R. Estudos Críticos em Administração: a Produção Científica Brasileira nos Anos 1990. RAE - Revista de Administração de Empresas, vol. 43, n. 4, out-dez 2003. Disponível em: <http://www.scielo.br/pdf/rae/v43n4/ v43n4a06.pdf $>$ Acesso em: 23 de outubro de 2015.

DEMO, P. Sociedade provisória - perspectivas de uma metodologia processual dialética. In: Metodologia científica em ciências sociais. São Paulo: Atlas, 1985.

DEWEY, J. Vida e educação. Tradução e estudo preliminar por Anísio Teixeira. São Paulo: Edições Melhoramentos, 1965.

DOMINGUES, I. Em busca do método. In: DOMINGUES, I. (Org.). Conhecimento e transdisciplinaridade II: aspectos metodológicos. Belo Horizonte: IEAT/Editora UFMG, 2005.

ETKIN, J. Gestion del capital social y la organización sustentable: La superación de ambivalencias en la dimensión humana y cultural. Documento de estudio para el Programa de Formación en Excelencia Gerencial. Facultad de Ciencias Económicas de la UBA. Buenos Aires, 2008.

ETKIN, J. Inteligencia política y superación de las tensiones en la organización. Revista Gestão e Planejamento, Salvador-BA, ano $7, \mathrm{n}^{\circ} 13$, jan./jun. 2006, p. 07-13. Disponível em: <http://www.spell. org.br/documentos/ver/27528/inteligencia-politicay-superacion-de-las-tensiones-en-la-organizacion> Acesso em: 23 de outubro de 2015.

FADUL, E.M.C.; MAC-ALLISTER DA SILVA, M.A. Limites e possibilidades disciplinares da administração pública e dos estudos organizacionais. RAC - Revista de Administração Contemporânea, v. 13, n. 3, p. 351-365, jul/ago, 2009. Disponível em: <http://www.scielo.br/pdf/ $\mathrm{rac} / \mathrm{v} 13 \mathrm{n} 3 / \mathrm{v} 13 \mathrm{n} 3 \mathrm{a} 02>$ Acesso em: 23 de outubro de 2015.

FARIA, J. H. Teoria crítica em estudos organizacionais no Brasil: o estado da arte. Cadernos EBAPE. BR, v. 7, n. 3, artigo 8, Rio de Janeiro, Set. 2009. Disponível em: < http:/ /www. scielo.br/pdf/cebape/v7n3/a09v7n3.pdf > Acesso em: 23 de outubro de 2015.

FRANÇA FILHO, G. C. Decifrando a noção de paraeconomia em Guerreiro Ramos: a atualidade de sua proposição. Organizações \& Sociedade, v. 17, n. 52, art. 10, p. 175-197, 2010. Disponível em: <http://www.scielo.br/pdf/osoc/v17n52/10.pdf> Acesso em: 23 de outubro de 2015.

FISCHER, T. Alice através do espelho ou Macunaíma em Campus Papagalli? Mapeando rotas de ensino dos estudos organizacionais no Brasil. In: CHANLAT, J.F.; FACHIN. R.; FISCHER, T. (Orgs.). Análise das organizações: perspectivas latinas. Vol. 1.: Olhar histórico e constatações atuais. Porto Alegre: Ed. da UFRGS, 2006. 
FORTIN, R. Compreender a complexidade. Introdução a $O$ método de Edgar Morin. Lisboa: Instituto Piaget, 2007.

FRANÇA FILHO, G. C. Para um olhar epistemológico da administração: problematizando o seu objeto. In: SANTOS, R. S. (Org.). A administração política como campo do conhecimento. São Paulo: Mandacaru, 2004.

GAIGER, L. I. A Economia Solidária e a revitalização do paradigma cooperativo. Revista Brasileira de Ciências Sociais, vol.28 n. 82, São Paulo, jun./2013. Disponível em: <http://sies. ecosol.org.br/images/resultado/economia_solidaria. pdf> Acesso em: 23 de outubro de 2015.

GARDNER, H. Inteligência: um conceito reformulado. Rio de Janeiro: Objetiva, 2001.

GAULEJAC, V. Gestão como doença social: Ideologia, poder gerencialista e fragmentação social. Aparecida - SP, Ideias \& Letras, 2007.

GIANNOTTI, J. A. A universidade em ritmo de barbárie. São Paulo: Brasiliense, 1986.

GIROLETTI, D. Administração no Brasil: potencialidades, problemas e perspectivas. RAE - Revista de Administração de Empresas. Vol. 45. Edição Especial Minas Gerais. 2005. Disponível em: <http://www.scielo.br/pdf/rae/v45nspe/ v45nspea09.pdf $>$ Acesso em: 23 de outubro de 2015.

GREY, C. Um livro bom, pequeno e acessível sobre estudos organizacionais. $2^{\mathrm{a}}$ ed. Porto Alegre: BOOKMAN, 2010.

GRISALES, R. M. Formar em administración: por una nueva fundamentación filosófica. Bogotá: Siglo del Hombre Editores, Universidad EAFIT, 2011.

GUERREIRO RAMOS, A. A nova ciência das organizações: uma reconceituação da riqueza das nações. $2^{\circ}$ ed, Rio de Janeiro: Ed da Fundação Getúlio Vargas, 1989.

GUERREIRO RAMOS, A. A redução sociológica: Introdução ao estudo da razão sociológica. Instituto Superior de Estudos Brasileiros. Rio de Janeiro: 1958.

GUERREIRO RAMOS, A. Homem-organização e homem-parentético. In: GUERREIRO RAMOS, A. Mito e verdade da revolução brasileira. Rio de Janeiro, Zahar Editores, 1963.

GUERREIRO RAMOS, A. Modelos de homem e teoria administrativa. RAP - Revista de

Administração Pública. Rio de Janeiro, v. 18, n.2, p. 3-12, abr/jun 1984. Disponível em: <http:// bibliotecadigital.fgv.br/ojs/index.php/rap/article/ view/10559/9557> Acesso em: 23 de outubro de 2015.

HENDERSON, H.; SETHI, S. Mercado ético: a força do novo paradigma empresarial. São Paulo: Cultrix, 2007.

HOLANDA, S. B. de. Raízes do Brasil. 13a edição. Rio de Janeiro: J. Olympio, 1979.

INEP - Instituto Nacional de Estudos e Pesquisa Anísio Teixeira. Resumo técnico: senso da educação superior 2009. Brasília: INEP, 2010. 37 p.

INEP - Instituto Nacional de Estudos e Pesquisa Anísio Teixeira. Sinopses Estatísticas da Educação Superior - Graduação. Brasilia/DF, 2013.

\section{LEISINGER, K. M.; SCHMIT'T, K. Ética} empresarial: responsabilidade global e gerenciamento moderno. Petrópolis: Vozes, 2001.

LE MOIGNE, J-L. La théorie du système général - théorie de la modélisation. Paris: Presses Universitaires de France, 1977.

LAW, J. Organization, narrative and strategy. In: HASSARD, J., PARKER, M. (Orgs.). Towards a new theory of organizations. Londres: Routledge, 1994, p. 248-268.

\section{MARIOTTI, H.; ZAUHY, C. Gestão da} complexidade: Ferramentas conceituais e práticas. Disponível em: $<$ http://www.humbertomariotti. com.br/gestao.html> Acesso em: 17 de janeiro de 2014.

MORIN, E. Le paradigme perdu: la nature humaine. Paris: Editions du Seuil, 1973.

MORIN, E. O método 5: a humanidade da humanidade. Porto Alegre: Sulina, 2002.

MORIN, E. A via para o futuro da humanidade. Rio de Janeiro: Bertrand Brasil, 2013.

MORIN, E. Complejidad restringida y complejidad generalizada o las complejidades de la Complejidad.

Utopía y Praxis Latinoamericana, vol. 12, núm.

38, julio-septiembre, 2007a, pp. 107-119, Universidad del Zulia, Maracaíbo, Venezuela. Disponível em: $<$ http://www.scielo.org.ve/pdf/upl/v12n38/art09. pdf> Acesso em: 23 de outubro de 2015.

MORIN, E. Em busca dos fundamentos perdidos: textos sobre o marxismo. $2^{\mathrm{a}}$ ed. Porto Alegre: Sulina, 2004. 
MORIN, E. Restricted complexity, general complexity. In: GERSHENSON, C.; AERTS, D.; EDMONDS, B., Worldviews, science and us: Philosophy and complexity. Singapore: World Scientific Pub Co Inc., 2007b.

MOTTA, F. P. Organização \& poder: empresa, estado e escola. São Paulo: Atlas, 1986.

MOTTA, F. P. Teoria das organizações: evolução e crítica. $2^{a}$ ed. revista e ampliada. São Paulo: Pioneira Thomson Learning, 2003.

NICOLINI, A. Qual será o futuro das fábricas de administradores? Revista de Administração de Empresas - RAE, vol. 43, no 2, p.43-54, abr./maio/ jun./2003.

PAES-DE-PAULA, A. P. Teoria crítica nas organizações. São Paulo, Thompson Learning, 2008.

PAES-DE-PAULA, A. P.; MARANHÃO, C. M. S. A.; BARRETO, R. O.; KLECHEN, C. F. A tradição e a autonomia dos Estudos Organizacionais Críticos no Brasil. RAE - Revista de Administração de Empresas. Vol.50, n.1, jan./mar. 2010. Disponível em: < http://www.scielo.br/pdf/rae/v50n1/ a02v50n1.pdf> Acesso em: 23 de outubro de 2015.

REED, M. Teorização organizacional: um campo historicamente contestado. In: CLEGG, S. R.; HARDY, C.; NORD, W.R. Handbook de estudos organizacionais: modelos de análise e novas questões em estudos organizacionais. São Paulo: Atlas, 1998.

RIBEIRO, D. A.; SACRAMENTO, A.R.S. Ensino e currículo em administração: a opção brasileira. Revista Gestão e Planejamento, Salvador-BA, V. 10, no 2, p. 193-205, jul./dez. 2009.

RODRIGUES, S. B.; CARRIERI, A. P. A Tradição Anglo-Saxônica nos Estudos Organizacionais Brasileiros. RAC - Revista de Administração Contemporânea, Edição Especial 2001: 81-102. Disponível em: < http://www.scielo.br/pdf/rac/ v5nspe/v5nspea05> Acesso em: 23 de outubro de 2015.

ROULEAU, L. Emoção e repertórios de gênero nas organizações. In: DAVEL, E.; VERGARA, S. (Orgs.) Gestão com pessoas e subjetividade. São Paulo: Atlas, 2007.

SANTOS, B. S. A Crítica da razão indolente: contra o desperdício da experiência. São Paulo: Cortez, 2011.
SARAIVA, L. A. S. A educação superior em administração no Brasil e a questão da emancipação: um túnel no fim da luz? Revista Gestão e Planejamento, Salvador, v. 12 , n. 1, p. 41-60, jan./ jun. 2011. Disponível em: < http:/ / www.revistas. unifacs.br/index.php/rgb/article/view/1296/1230> Acesso em: 23 de outubro de 2015.

SÉGUIN, F.; CHANLAT, J-F. (Orgs.) L'analyse de organisations: une anthologie sociologique. Tome 1 Les théories de l'organisation. Montréal: Gaëtan Morin Éditeur Itée, 1992.

SERVA, M. A importação de metodologias administrativas no Brasil - uma análise semiológica, in RAP - Revista de Administração Pública, 26(4):128-44, out/dez 1992. Disponível em: <http:// bibliotecadigital.fgv.br/ojs/index.php/rap/article/ view/8751/7480> Acesso em: 23 de outubro de 2015.

SILVA, A. O. Maurício Tragtenberg: militância e pedagogia libertária. Ijuí: Ed. Unijuí, 2008.

SINAY, M. C. F.; DALBEM, M. C.; LOUREIRO, I. A.; VIEIRA, J. M. Ensino e pesquisa em gestão ambiental nos programas brasileiros de pós-graduação em administração. Revista de Administração Mackenzie, v. 14, n. 3, p. 55-82, 2013. Disponível em: <http://www.scielo.br/pdf/ $\mathrm{ram} / \mathrm{v} 14 \mathrm{n} 3 / \mathrm{a} 04 \mathrm{v} 14 \mathrm{n} 3 . \mathrm{pdf}>$ Acesso em: $23 \mathrm{de}$ outubro de 2015.

SORJ, B. A nova sociedade brasileira. Rio de Janeiro: Jorge Zahar, 2000.

SOUZA, J. A tolice da inteligência brasileira: ou como o país se deixa manipular pela elite. São Paulo: LeYa, 2015.

SOUZA-SILVA, J. C.; DAVEL, E. Concepções, práticas e desafios na formação do professor: examinando o caso do ensino superior de administração no Brasil. Organizações \& Sociedade, Salvador, v. 12 , n. 35 , p. 113 - 134, out./ dez. 2005.

TRAGTENBERG, M. A delinqüência acadêmica: o poder sem saber e o saber sem poder. São Paulo: Rumo Gráfica Editora, 1979.

TRAGTENBERG, M. Administração, poder e ideologia. São Paulo: Ed. Moraes, 1980.

TRAGTENBERG, M. Burocracia e ideologia. São Paulo: Ed. Ática, 1985.

TRAGTENBERG, M. Memórias de um autodidata no Brasil. São Paulo, Ed. Escuta, 1999. 